\title{
CAN INFECTION WITH CYTOMEGALOVIRUS, PARVOVIRUS B19 AND HERPES SIMPLEX VIRUS CAUSE RECURRENT PREGNANCY LOSS?
}

\author{
Hossam Goda MD*, Osama M. Warda MD*, El-Said A. Hady PhD MRCOG*, \\ Mohamed Nezar MD*, Maisaa El-Said MD**, Abdel-Aziz,El-Refaie MD, \\ and Ahmad Ragab MD*
}

From the Department of Obstetrics \& Gynecology*, and the Department of Clinical Pathology**: Faculty of Medicine, Mansoura University .

\section{ABSTRACT}

Objective: This study aimed to assess the probability of cytomegalovirus, parvovirus B 19, and herpes simplex I, 2 virus infection to cause recurrent miscarriage.

Study Design: Prespective study.

Settings: Antenatal outpatient clinic of Mansoura University Hospital and Clinical pathology department, faculty of Medicine, Mansoura University during the period from February 2005 to September 2006

Methods: Patients included in the study were collected from those attending the antenatal outpatient clinic of Mamsoura University Hospitals and were grouped into 2 groups; those with prior recurrent miscarriage ( 3 or more), with no uterine malformation that may be a cause of recurrent miscarriage (excluded by hysterosalpingograms) ( $(n=50)$. The other group included 12 women with normal pregnancy used as control. Blood samples were taken from each woman \& sent to the clinical pathology department for detection Ig M by ELISA \& PCR for the genomes.

Results: Parvovirus IgM had the highest rate (84\%) followed by HSVI, $2 \operatorname{IgM}(50 \%)$ and CMV IgM (12\%) in 1 he recurrent abortion group. In controls, only parvovirus B $19 \mathrm{IgM}$ was positive in 2 cases $(16.7 \%)$. In PCR study for viral DNA, parvovirus B 19 was positive in 24 cases (48\%), HSV2 in 16 cases (32\%) and CMV was positive in 6 ciases $(12 \%)$ in recurrent abortion group with statistically significant difference between both groups.

Conclusion: We can conclude that viral infections might play a role in recurrent abortion especially parvovirus B 19 and HSV2.

Key words: Parvovirus B 19, Herpes simplex, cytomegalovirus, PCR, Recurrent miscarriage.

\section{INTRODUCTION}

Some evidence suggests that intrauterine infections play a major role in the pathogenesis of early pregnancy loss, but the implication and prevalence of microorganisms in the etiology of spontaneous abortion during the first trimester of pregnancy has not yet been well established (1).

The cytomegalovirus (CMV) and parvovirus B19 are linked to both late abortions and still birth $(2,3)$
Parvovirus B19 infections are associated with different clinical manifestations that vary from symptomless to severe symptoms. The main clinical manifestations are erythema infectiusum, transient aplastic crisis in individuals with hemoglobinopathies, chronic anemia in the immuno-compromised, acute polyarthralgia syndrome in adults, hydropes fetalis, spontaneous abortion and still birth. Persistent or recurrent B 19 infections can be associated with chronic clinical

Corresponding author: Osama M Warda MD, Obstetrics \& Gynecology Department, Faculty of Medicine, Mansoura University, Tel: 0127457532,E-Mail: om2warda@yahoo.com. 
manifestations or with transient clinical syndromes generally due to recrudescence of viral replication (4).

Since the infection has been associated with wide varieties of clinical manifestations and some clinical features of B19 infection such as anemia or rash, can be common to other pathogens, a laboratory diagnosis of $\mathrm{B} 19$ is required. A diagnostic protocol must consider both the type of pathology and the type of patient. In immuno-competent individuals virological and serological testing is complementary, while in immuno-compromized patients viral detection is the diagnosis of choice. Viral detection methods are generally based, nowadays, on direct detection of B19 genome in clinical samples (5).

Genital herpes is the result of infection by herpes simplex type 2 (HSV-2) and to lesser extent herpes simplex type 1 (HSV-1). Recent years have seen a rise in the prevalence of genital HSV infection in both industrialized and developing countries. The main factor contributing to the spread of HSV include asymptomatic virus shedding and under-recognition and under-diagnosis of the disease. At the level of the individual patient, genital herpes is associated with significant psychological morbidity and complications such as neonatal herpes, the result of transmission of HSV from mother to baby (6).

The incidence of asymptomatic cervical infection with HSV-2 was considerably higher in patients with a history of spontaneous abortion with a possible etiological connection between HSV and spontaneous abortion (7).

Serological assays were not very useful for the elucidation of the role of HSV in inducing spontaneous abortions, although they indicate that the state of pregnancy predisposes to HSV reactivation (8).

This study aimed to assess the probability that infection with cytomegalovirus, parvovirus B19, and herpes simplex 1,2 virus to cause recurrent miscarriage.

\section{PATIENTS \& METHODS}

The patients were recruited from the Antenatal Clinic, Mansoura University Hospital. Two different groups were evaluated. The first group consists of normal pregnant women $(n=12)$ with pregnancy duration of more than 24 weeks. The second group comprised 50 women with recurrent abortion (history of 3 or more consecutive spontaneous abortions including abortions up to 22 gestational wecks). Demographic, medical and clinical data were collected in each case based on personal interviews and medical examination. Cases included in the study group were subjected to hysterosalpingography and those with uterine anomalies were excluded from the study. The women signed an informed consent before they were included in the study.

Sera collection:

Blood samples were obtained from each patient by venipuncture, centrifuged and sera kept frozen in 4 aliquots at $-20^{\circ} \mathrm{C}$ until analysis.

Sera analysis:

Serum samples from each woman were analyzed for specific IgM for CMV, HSV1/2 (ELISA-Equipar) and parvovirus B 19 (ELISA-IBL). Also, PCR was performed for each woman to detect specific DNA of CMV (Expeateam) HSV1/2 and parvovirus B19 (ABAnalytica).

\section{PCR for CMV}

Kit for the detection of CMV DNA included all reagents for DNA extraction, nested PCR amplification of glycoprotein B gene and visualization by agarose gel electrophoresis.

DNA of CMV was extracted from serum sample by QiAamp DNA mini kit.

\section{Amplification procedure:}

For each sample was prepared the following 
mixture: buffer $(2.5 \mu \mathrm{l})$, dNTPs $(2.5 \mu \mathrm{l})$, primer Pl $(1.0 \mu \mathrm{l})$, primer $\mathrm{P} 2(1.0 \mu \mathrm{I})$, Tag polymerase $(0.3 \mu \mathrm{I})$, distilled water $(7.7 \mu \mathrm{l})$, DNA solution $(10 \mu \mathrm{I})$ and overlaid by mineral oil $(30 \mu \mathrm{I})$. Amplification program was $94^{\circ} \mathrm{C}$ for $1 \mathrm{~min}, 55^{\circ} \mathrm{C}$ for $1 \mathrm{~min}, 72^{\circ} \mathrm{C}$ for 1 min, for 30 cycles.

\section{Analysis of amplified products:}

Finally, the 221 bp fragment PCR amplicons were electrophoresd in agarose gel $(2 \%)$ and determined by comparison with standard molecules size marker (Amarsham) to cxclude carry over concamination, water as negative control was processesed in the same manner as samples.

\section{Nested PCR for HSV 1/2:}

PCR kit for HAV 1/2 DNA detection including all retgents for DNA extraction, nested multiplex PCR amplification and visualization by agarose gel electrophoresis. There is internal control for the amplilication process including B-globin amplification.

The viral DNA extraction system is based on high binding capacity resins that ensures a good extraction yield.

\section{Anplification protocol:}

First multiplex HSVI/2 DNA amplification: Add to each premixed supplied tubes Tag. $0.25 \mu$ and 10 HI ol extracted DNA. Negative control was analyzed by adding water instead of DNA and positive control was performed by $5 \mu \mathrm{I}$ of HSVI positive control and $5.0 \mu 1$ of positive control HSV2 DNA supplied with the kit. For B-globin DNA amplification; add to each premixed test tube specific for B-globin Tag polymerase $0.2 \mu \mathrm{I}$ and extacted DNA $20 \mu \mathrm{I}$.

The following program was used for thermal cycler; I cycle at $94^{\circ} \mathrm{C}$ for $2 \mathrm{~min}, 35$ cycles $\left(94^{\circ} \mathrm{C}\right.$ for $30 \mathrm{sec}, 56^{\circ} \mathrm{C}$ for $30 \mathrm{sec}, 72^{\circ} \mathrm{C}$ for $30 \mathrm{sec}$ ) 1 cycle $72^{\circ} \mathrm{C}$ for $5 \mathrm{~min}$.

Second multiplex amplilication of HSV 1/2: From amplified product take 1 بI DNA and $0.25 \mu \mathrm{l}$ of Tag polymerase in premixed tubes supplied with the kit. The program used in the thermal cycles was 1 cycle $94^{\circ} \mathrm{C}$ for $2 \mathrm{~min}$., 30 cycles $\left(94^{\circ} \mathrm{C}\right.$ for $30 \mathrm{sec} ., 58^{\circ} \mathrm{C}$ for 30 sec., $72^{\circ} \mathrm{C}$ for $30 \mathrm{sec}$.), 1 cycle at $72^{\circ} \mathrm{C}$ for 5 min.

Analysis of the simplification Products: Electrophoresis was performed on $2 \%$ agarose gel with ethedium bromide. The fragment size was 137 bp for HSV1 and 100 bp for HSV2. The bands were compared with the positive control supplied with the kit and with standard molecular weight marker.

\section{PCR for Parvovirus B19:}

It is PCR for detection of DNA of human Parvovirus B19. It contains internal control for amplification of B-globin DNA. The amplitication target seguence from B19 genome nucleotides: $1390-1608$

Alter DNA extraction, the following protocol ol amplification was used: add to the supplied mix tubes $0.2 \mu \mathrm{l}$ Tag polymerase, $10 \mu \mathrm{I}$ DNA. Add $10 \mu \mathrm{I}$ waller to one tube to be used as negative control and $10 \mu \mathrm{I}$ of positive control supplied with the kt. The program of the thermal cycler was $95^{\circ} \mathrm{C}$ for 5 min, 4 e cycles (95 ${ }^{\circ} \mathrm{C}$ for 1 min., $54^{\circ} \mathrm{C}$ for 1 min., $72^{\circ} \mathrm{C}$ for 1 min.) and 1 cycle $72^{\circ} \mathrm{C}$ for 5 min.

Analysis of the amplified products: Analysis of the amplified products was performed by clectrophoresis on $2 \%$ gel with ethidium bremide. The B19 product wals 218 bp long and B-globin $\mathrm{P} C \mathrm{CR}$ was 268 hp long.

\section{Statistical analysis}

Statistical antalysis was performed using Statisticat 'y9 software (StatSolt, Tulsa, Okla.). Data were kested for nomality using Kulmogonov-Smirnow kast. Unpatied Student's 1 lest was performed to compario the parametric values of the two groups. Manm Whitney U test was performed to compatre the nonjparametric values of the two groups. Data were expressed as frequency, mean $\pm S D$, pereentage 
median (range). A value of $\mathrm{P}<0.05$ was considered to represent statistical significance.

\section{RESULTS}

The study was carried out on 50 patients complaining of recurrent abortions; forty cases $(62.5 \%)$ were in first trimester and ten cases (15.6\%) were in second trimester. There were twelve cases with normal pregnancy included as control group. The mean age \pm SD of the patients was $(26.86 \pm 5.61$ years) and the mean age of the control group was $(26.2 \pm 6.25$ years $)$ with statistically insignificant difference between both groups $(P=0.76)$. The range of gravidity in both groups was 2-7 times.

In the study of serological response for the studied viruses, parvovirus IgM had the highest rate (84\%), followed by HSVI/2 IgM (40\%) and CMV IgM $(12 \%)$. In the control group only parvovirus IgM was positive in two cases $(16.7 \%)$. There was a statistically significant difference between patients group and control group in prevalence of parvovirus $\operatorname{IgM}(\mathrm{P}=0.001)$ and $\mathrm{HSV} 1 / 2 \operatorname{IgM}(\mathrm{P}=0.001)$.

In PCR study for viral DNA, parvovirus B19 was positive in 24 cases (48\%), herpes simplex 2 PCR was positive in 16 cases (32\%) and CMV PCR was positive in 6 cases $(12 \%)$. There was a statistically significant difference between the patients group and control group in parvovirus PCR and HSV2 PCR $(\mathrm{P}=0.002, \mathrm{P}=0.022$ respectively).

In comparison of $\operatorname{IgM}$ for the studied viruses and their DNA detection by PCR, for CMV IgM the sensitivity, specificity, accuracy, positive predictive value and negative predictive value were $100 \%$.

The sensitivity of parvovirus IgM was $100 \%$, specificity was $47.4 \%$, accuracy was $67.7 \%$, positive predictive value was $54.5 \%$ and negative predictive value was $100 \%$.

The sensitivity of HSV2 IgM was $100 \%$, specificity was $93.5 \%$, positive predictive value was
$80 \%$ and negative predictive value was $100 \%$.

From positive parvovirus IgM cases, the mean SD of IgM value for PCR positive cases was $78.5 \pm 30.12$ and for negative PCR it was 30.02417 .64 with statistically significant difference between both levels $(\mathrm{P}<0.001)$.

\section{DISCUSSION}

Seventy-one women were selected from the Antenatal Care Clinic of Mansoura University Hospital for this study; 12 women served as normal pregnant controls and fifty-nine with recurrent miscarriage (of the latter, 7 women were excluded due to uterine anatomical abnormalities diagnosed by HSG). Two women were excluded as they refused to sign the informed consent, thus the study group included 50 women.

The highest incidence was for parvovirus BI9 $\operatorname{IgM}(84 \%)$ followed by HSV2 IgM (40\%) and CMV $\operatorname{IgM}(12 \%)$. It was reported that parvovirus IgM was detected in $36.4 \%$ from random female samples in Taiwan (10). In Kuwait, seroprevalence of parvovirus $\mathrm{IgG}$ and $\mathrm{IgM}$ were $53.3 \%$ and $2.2 \%$ respectively in normal pregnant females with seroconversion rates $16.5 \%$ (9). In a Swedish study, the prevalence of parvovirus antibody was $81 \%$ with $6.8 \%$ seroconversion after labour (11). In Russia. the positivity of B $19 \mathrm{IgG}$ was $66.9 \%$ and for CMV it was $81.1 \%$ among pregnant aborters ${ }^{(12)}$.

The discrepancy between results of serological tests for parvovirus B 19 might be due to the difference of the studied populations. Also, the difference in gravidity might affect the rate of spread of parvovirus which is an infectious disease transmitted mainly by children (13), so with higher number of children around the pregnant female the possibility of infection increases. This also explains the presence of two positive cases in the control group. 
The lower rate of positivity of CMV IgM could be attributed to the fact that primasy CMV infection is usually acquired during childhood, so the serosusceptibility and the risk of primary infection is lower during pregnancy than other viruses. However, recurrent maternal infections can result in less damage to fetus (12).

HSV $1 / 2$ IgM was positive in $80 \%$ of infertile females with recurrent abortions (14). In another study, serology to HSV was positive in $32 \%$ of pregnant females (14). It seems that the state of pregnancy predisposes to $\mathrm{HSV}$ reactivation, so pregnant females either with recurrent abortions or with normal pregnancy displays serological markers of HSV reactivate (8). However in our study there was a significant increase of HSV in recurrent aborters over normal pregnant, which denotes that HSV may predispose to such condition.

DNA of parvovirus was detected in $48 \%$ of cases. The sensitivity of parvovirus IgM when compared to PCR was $100 \%$, specificity was $47.4 \%$, accuracy was $67.7 \%$. positive predictive value was $54.4 \%$ and negative predictive value was $100 \%$.

In another study carried on 29 pregnant women with hydrops fetalis after exclusion of leto-matemal incompatibility; 9 (31\%) had active parvovirus infection with positive DNA by PCR, only 3 of them had positive $\operatorname{lgM}(15)$. Lower rate of positivity for parvovirus was detected by others (4) which was 16 out of 212 cases with recurrent abortions.

In our study IgM correctly diagnosed all cases with positive PCR, but diagnosed one case with negative PCR which resulted in decrease in its specificity. However, these cases might have recent infection with positive serology while DNA was no longer detected.

On the other hand, DNA measurement is the best indicator of infection not only in the fetal blood but also in the matemal blood. This improves the diagnostic value of the laboratory results considerably. DNA assays are essential in cases of doubtful serological results ${ }^{(5)}$.

In a trial to improve the diagnostic value of parvovirus IgM, we evaluated the cut-off value which diagnoses all cases with positive PCR. The value was

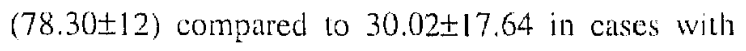
negative PCR. There was statistically significant difference $(\mathrm{P}=0.0001)$. This could be used as an approach to detect all positive cases of parvovirus B19 DNA. Another approach was by blotingr recessive operative curve to find values with improved specificity of parvovirus $\operatorname{IgM}$. The value was $48 \mathrm{Iu} / \mathrm{ml}$ with sensitivity $83.3 \%$, specificity was $66.7 \%$ accuracy was $89.2 \%$. So, it seems that cul-oll value for IgM to detect positive cases with aclive parvovirus infection had to be determined in each locality to decrease false positive reactions.

The second most common virus detected by PCR in recurrent aborters was HSV2 (32\%) with statistically significant difference between patients and controls $(\mathrm{P}=0.022)$.

Similarly, HSV2 DNA was detected among $48 \%$ of cases with recurrent aborters as reported by Manavi et al. (1992) (16). It seems that the stale of pregnancy predispose, to reactivation of latent virus infections which might results in fetal infection with spontaneous abortion (17). The serological study of HSV2 IgM secms accurate in diagnosis of HSV2 infection during pregnancy with specilicity was $91.3 \%$, accuracy was $93.5 \%$, positive predictive value was $80 \%$ and negative predictive value was $80 \%$ ).

CMV- DNA wals detected by PCR in 6 calses (12\%) of the patients and in 2 cases in the comtliul group. The CMV IgM sensitivity, specificity, aceuracy positive predictive value were $100 \%$. The lower rate of positivism of CMV in our study could be altributed to that primary CMV infection during pregnancy is connected mainly to second and third trimester complications (18), while our patients were mainly in first trimester. 
The serological test for diagnosis of CMV infection was valuable with excellent results and so we can depend upon it for diagnosis during pregnancy.

From this study we could conclude that viral infections might play a role in recurrent abortions especially parvovirus B19 and herpes simplex 2 . Serological study specific IgM for parvovirus, HSV2 and CMV seem to be accurate as a screening test for high risk pregnancy. The cut-off value of parvovirus IgM appear to be higher for patients in our locality. DNA determination by PCR in maternal serum improves the diagnostic value of serological tests.

\section{REFERENCES}

1. Penta M, Lukic A, Conte MP et al.: Infectious agents in tissue from spontaneous abortions in the first trimester of pregnancy. New Microbiol., (2003); 26/4:329-37.

2. Levy R, Werssman A, Blomberg G et al.: Infection by parvovirus $\mathrm{B} 19$ during pregnancy: a review. Obstet Gynecol Surv., ( ); 52: 254-259.

3. Lazzarotto $\mathrm{T}$, Varani S, Spezzacatena $\mathrm{P}$ et al.: Maternal IgG and IgM detected by blot as diagnostic tools to identify pregnant women at risk of transmitting cytomegalovirus. Viral Immunol., (2000); 13: 137-141.

4. Wermelinger MC, Delemann WM, Lina deMendonca MC et al.: Detection of human parvovirus B 19 infection: a study of 219 suspected cases in the state of Rio de Janeiro, Brazil, J. Clin.Virol., (2002); 25/2: 223-30.

5. Zerbini M, Gallinella G, Cricca $M$ et al.: Diagnostic procedures in B19 infection. Pathol. Biol. (Paris) (2002); 50/5: 332-8.

6. Cusini M, Ghislanzoni $M$ : The importance of diagnosing genital herpes. J Antimicrob Chemother., (2001); 47:19-16.

7. Bujko M, Sulovic V, Zivanovic V et al.: Herpes simplex virus infection in women with previous spontaneous abortions. J Perinat Med., (1998); 16; 3: 193-6.
8. Sifakis S, Koumantakis E, Koffa M et al.: Detection of herpes simplex virus (HSV) in aborted material using the polymerase chain reaction technique. Gynaecol. Obstet. Invest., (1998); 45/2:109-15.

9. Maksheed M, Pacsa AS, Essa SS et al.: The prevalence of antibody to human parvovirus B 19 in pregnant women in Kuwait. Acta. Trop., (1999); 15:73/2:925-9.

10. Lin KH, You SL, Chen CJ et al.: Seroepidemiology of human parvovirus B19 in Taiwan. J of Med. Virol., (1999); 5712:169-173.

11. Skjoldebrand-Sparre L, Tefventamt, Papadogiannakis $\mathrm{N}$ et al.: Parvovirus B19 infection: association with third trimester intrauterine fetal death. $\mathrm{Br}$. J. Obstet. Gynaecol., (2000); 107:476-480.

12. Odland J. Sergejeva IV, Ivaneev MD et al.: Seropositivity of cytomegalovirus, parvovirus and rubella in pregnant women and recurrent aborters in Leningrad county, Russia. Acta. Obstetricia Eı Gyn. Scandin., (2001); 80/11:1025.

13. Panam Jensen L, Thorsen P, Jeune B et al.: An epidemic of parvovirus B 19 in a population of $354 \mathrm{~K}$ pregnant women: a study of sociodemographic and medical risk factors. Br. J Obstet Gynaenol., $(2000)$; 107: 637-643.

14. Huang LI, Zhang $Z$ : The relationship between herpes simplex virus 11, human papilloma virus infection and infertility after artificial abortion. Zhonghua Shi Yan He Lin Chuang Bing Du Xue Za Zhi (1998): 12/2:155-7.

15. Geburt Shilf, Gallinela G., Zulfi E, Gentilomi G. et al.: Relevance of B 19 markers in serum samples for a diagnosis of parvovirus B19 correlated diseases. J of Med Virol., (2003); 71/1:135-139.

16. Frenkel LM, Garratty EM, Shen JP: Clinical reactivation of herpes simplex virus type 2 infection in seropositive pregnant women with no history of genital herpes. Ann. Intern. Med., (1993); 118/6: 414-8.

17. Manavi M, Czerwenka KF, Schurz B et al:: Latent cervical virus infection as possible cause of early abortion. Gynacol Geburtshifliche Rundsch., (1992); 32/2:84-7.

18. Szkadkiewicz A, Pieta P, Tulecka $T$ et al.: The diagnostic value of anti-CMV and anti-HPV-B 19 antiviral antibodies in studies on causes of recurrent abortions. Ginekol. Pol., (1997); 68/4:181-6. 
Table I : Demographic data of the studied 2 groups.

\begin{tabular}{|l|c|c|c|}
\hline & $\begin{array}{l}\text { Patients } \\
(\mathrm{N}=50)\end{array}$ & $\begin{array}{c}\text { Controls } \\
(\mathrm{N}=\mathbf{1 2})\end{array}$ & Test \\
\hline $\begin{array}{l}\text { Age } \\
\text { (Mean } \pm \mathrm{SD})\end{array}$ & $26.8 \pm 5.61$ & $26.2 \pm 6.25$ & \begin{tabular}{l}
$\mathrm{P}=0.30$ \\
\hline $\begin{array}{l}\text { Gravidity } \\
\text { Median (Range) }\end{array}$
\end{tabular} \\
\hline $\begin{array}{l}\text { Time of abortion: } \\
\text { First Trimester } \\
\text { Second Trimester }\end{array}$ & $4(2-7)$ & $5(2-7)$ & $\begin{array}{l}\text { Chi Sq. }=2.01 \\
\mathrm{P}=0.84\end{array}$ \\
\hline
\end{tabular}

Table II : Serological results of CMV, parvovirus, and HSV2 IgM .

\begin{tabular}{|l|c|c|c|c|c|}
\hline & \multicolumn{2}{|c|}{ Patients } & \multicolumn{2}{c|}{ Controls } & \multirow{2}{*}{ Test } \\
\cline { 2 - 5 } & No & $\%$ & No & $\%$ & \\
\hline CMV IgM: & & & & & \\
Positive & 6 & 12 & 0 & 0 & \multirow{2}{*}{ Chi Sq. $=1.59$} \\
Negative & 44 & 88 & 12 & 100 & P $=0.20$ \\
\hline Parvovirus IgM: & 42 & 84 & 2 & 16.7 & Chi Sq. $=21.129$ \\
Positive & 8 & 16 & 10 & 33.3 & P<0.001 \\
Negative & 20 & 40 & 0 & 0 & Chi Sq. $=7.08$ \\
\hline Herpes 1/2: & 30 & 60 & 12 & 10 & P $=0.001$ \\
Positive & & & & & \\
Negative & & & & & \\
\hline
\end{tabular}

Table III : PCR results of DNA detection for CMV, parvovirus and HSV2.

\begin{tabular}{|c|c|c|c|c|c|}
\hline & \multicolumn{2}{|c|}{ Patients } & \multicolumn{2}{|c|}{ Controls } & \multirow{2}{*}{ Test } \\
\hline & No & $\%$ & No & $\%$ & \\
\hline CMV PCR: & & & & & \\
\hline Posilive & 6 & 12 & $1)$ & 0 & $\operatorname{Chi} S_{4}=1.54$ \\
\hline Negative & 44 & 88 & 12 & 100 & $P=0.20$ \\
\hline Parvovirus PCR: & & & & & \\
\hline Positive & 24 & 48 & 2 & 16.7 & Chi $S_{4}=9.39$ \\
\hline Negative & 26 & 52 & 10 & 33.3 & $P<0.002$ \\
\hline Herpes $1 / 2$ & & & & & \\
\hline Posilive & 16 & 32 & 0 & () & Chi Sy. $=5.17$ \\
\hline Negative & 34 & 68 & 12 & 10 & $P=0.022$ \\
\hline
\end{tabular}


Table IV : Comparative study between IgM and PCR for the studied viruses.

\begin{tabular}{|l|c|c|c|c|c|}
\hline & Sensitivity & Specificity & Accuracy & $\begin{array}{c}\text { Positive } \\
\text { predictive } \\
\text { Value }\end{array}$ & $\begin{array}{c}\text { Negative } \\
\text { predictive } \\
\text { Value }\end{array}$ \\
\hline CMV & $100 \%$ & $100 \%$ & $100 \%$ & $100 \%$ & $100 \%$ \\
\hline Parvovirus IgM & $100 \%$ & $47.4 \%$ & $67.7 \%$ & $54.5 \%$ & $100 \%$ \\
\hline Herpes I IgM & $100 \%$ & $91.3 \%$ & $93.5 \%$ & $80 \%$ & $100 \%$ \\
\hline
\end{tabular}

Table V : Parvovirus IgM value for PCR positive and negative results.

\begin{tabular}{|l|c|c|}
\hline \multicolumn{1}{|c|}{ Parvovirus IgM positive } & PCR positive & PCR negative \\
\hline Meill \pm SD & $78 \pm 30.12$ & $30.02 \pm 17.64$ \\
\hline t test & 7.99 & \\
\hline P waluc & $<0.001$ & \\
\hline
\end{tabular}

